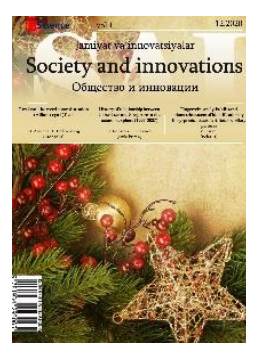

\title{
Development irrigation and agriculture in the Ferghana valley (as an example 50-70-s of the XX century)
}

\section{Oybek KOMILOV ${ }^{1}$}

Andizhan State University named after Babur

\author{
ARTICLE INFO \\ Article history: \\ Received September 2020 \\ Received in revised form \\ 15 October 2020 \\ Accepted 15 November 2020 \\ Available online \\ 31 December 2020

Keywords:
Ferghana valley
Agriculture
Irrigation-land-reclamation
Cotton monopoly
Soviet government
Irrigation system
Collective farm
State farm
Drainage
Collector
Virgin lands

\section{ABSTRACT}

In the article the state of irrigation-land-reclamation of Ferghana valley in the condition of cotton monopoly in 19501970 is closely observed. Besides, the measures on improvement of agriculture and irrigation system by Soviet government and their results are analyzed in the article on the grounds of primary sources.

\section{1-1415/C 2020 in Science LLC.}

This is an open access article under the Attribution 4.0 International (CC BY 4.0) license (https://creativecommons.org/licenses/by/4.0/deed.ru)

\section{Фарғона водийсида ирригация ва қишлоқ хужалиги ривожланиши (XX асрнинг 50-70 йиллар мисолида)}

\footnotetext{
Ключевые слова:

Фарғона водийси

Қишлоқ хўжалиги

Суғориш-мелиорация

Пахта яккахокимлиги

Совет хукумати
}

\section{АННОТАЦИЯ}

Мазкур мақолада 1950-1970 йилларда Фарғона водийсидаги пахта яккахокимлиги шароитида суғориш ва мелиоратив эрларнинг холати батафсил кўриб чиқилган. Бундан ташқари, мақолада Совет хукуматининг қишлоқ хўжалиги ва суғориш тизимини такомиллаштириш бўйича

\footnotetext{
${ }^{1}$ Doctor of Sciences in History, Professor at the department "Theory of civil society" of Andizhan State University named after Babur, Andizhan, Uzbekistan

E-mail: oybek.komilov@bk.ru
} 
Суғориш тизими

Колхоз

Совхоз

Дренаж

Коллектор

Бокира эрлари чоралари хамда уларнинг натижалари

дастлабки манбаларга асосланган холда тахлил қилинган.

\section{Развитие ирригации и сельского хозяйства в Ферганской долине (на примере 50-70-х годов XX века)}

\author{
Ключевые слова: \\ Ферганская долина \\ сельское хозяйство \\ Орошение-мелиорация \\ Хлопковая монополия \\ Советское правительство \\ Система орошения \\ Колхоз \\ Совхоз \\ Дренаж \\ Коллекционер \\ Целинные земли
}

\section{АННОТАЦИЯ}

В статье

подробно

рассмотрено

состояние ирригационно-мелиоративных земель Ферганской долины в условиях хлопковой монополии в 1950-1970 гг. Кроме того, в статье на основе первоисточников анализируются меры Советского правительства по совершенствованию сельского хозяйства и ирригационной системы, а также и их результаты.

\section{INTRODUCTION}

It is known that during the years of Soviet rule in Uzbekistan, as well as in the agriculture of the Ferghana Valley, a policy of cotton monopoly was established, and irrigation was completely subordinated to it. The implementation of cotton monopoly has increased the dependence of the local population on grain, meat and milk on the supply of essential foodstuffs. It was in the $50 \mathrm{~s}$ and $70 \mathrm{~s}$ of the twentieth century that the colonial order was established in the Ferghana Valley. In particular, the Soviet government emphasized the need to further accelerate cotton production, especially in the Ferghana Valley, which has favorable natural conditions, climate and opportunities for cotton growing. In particular, the adoption of the Resolution of the Council of Ministers of the former USSR of September 2, 1952 "On irrigation and development of lands in Andizhan, Namangan and Fergana regions of the Uzbek SSR for further development of cotton" [9:14] is a clear proof of our opinion. The resolution considered the development of 65,000 hectares of protected lands in Central Ferghana (including 15,000 hectares of neglected lands in the irrigation network) in the next 4-5 years, from 1953. However, the adoption of this historic decision, in turn, indicates that the Soviet government's policy of cotton monopoly in the valley has intensified. A number of guidelines and tasks were developed by the governing bodies of the Soviet government for the rapid development of agriculture, especially cotton growing. At the September 1953 Plenum of the Central Committee of the CPSU, special emphasis was placed on the issue of short-term increases in cotton production. At the same time, the Plenum set the following tasks: "It is necessary to significantly increase the yield of cotton in collective and state farms and expand the area under cotton by using unused lands, developing new irrigated lands, as well as improving land reclamation" [7:436].

It should be noted that the main goal of the Soviets in this event was to provide the center with more raw cotton. As a result of the development of new lands, the cotton sector 
has accelerated, but has caused a number of serious problems in the health of the population. In 1953-1955 the number of developers in the collective farms of Namangan region was 48, and the newly developed lands were located mainly in Damkul, Akkum, Momokhan, Achchik Kul, Karakalpak, Mingbulak, Naiman and Boz massifs [8: 3]. Up to 810 quintals of cotton were harvested from one hectare of developed land. In the first year of the redeveloped lands in the collective farm "Gigant" of Zadarya (Mingbulak) district from 18 to 20 tons cotton was obtained up to [10: 3]. In 1953 the mobile collective farms of Central Ferghana managed to get a good harvest of cotton. In particular, the collective farm named after Kirov in Boz district up to 25.3 centners per hectare, the collective farm "Leninchi" in Kholdevonbek district (now part of Shahrikhan district) up to 26.4 centners per hectare, and the collective farm "Gigant" in Zadarya (Mingbulak) district up to 30.3 centners per hectare received a cotton crop up to tons [11:52].

The increase in productivity was due to the center's policy of so-called cotton monopoly. Its outbreak has led to a complete reduction in other crop areas. As a result, the needs of the population in other essential grain products were not met. In the same year, the farms of Boz district transferred 10,900 tons to the state under the contract. In practice, 16 thousand tons of cotton are grown per hectare, which is 8689 tons cotton was delivered and the plan was fulfilled by $80 \%$. In the implementation of the state plan for the production of cotton in the district, the collective farm "XVII Party Congress" has 863 hectares of cotton fields and 21.5 tons instead of 15.4 tons formed from. The state plan for cotton production was fulfilled by $71.6 \%$. Out of 13 kolkhozes in the district, 5 kolkhozes have 15 tons to, 7 kolkhoz 15 tons 20 tons and only one kolkhoz 25 tons. It grew up to 30 thousand tons of cotton [14: 7]. The figures also show that the district's agriculture was dominated by the cotton industry, and that the Soviet government's command plan in this area was gradually strengthened.

\section{METHODS}

The article uses the methods of comparative analysis and historical analysis of the materials in chronological order. In particular, the resolution of the Council of Ministers of the Union and the Central Committee of the CPSU of February 9, 1954 "On further development of cotton growing in the USSR in 1954-1958" expanded irrigation areas (600 thousand hectares, including 300 thousand hectares of cotton), significantly improved land reclamation, the regulation of water use in collective farms and state farms was considered [6:96]. This decision marked the beginning of a new phase of cotton monopoly in the Ferghana Valley. In particular, in the tasks for the development of cotton growing in the 6th five-year period (1956-1960) of Andizhan region in the perspective plan of collective farms to achieve 235.9 thousand hectares of irrigated land (including 158.6 thousand hectares of cotton) and 482.1 percent of total cotton production thousand tons, while increasing the total yield in the region from 30.4 hectares per hectare. In order to fulfill this task, during the remaining 4 years of the 6th Five-Year Plan period, the obligation to expand the area under cotton by 7.7 thousand hectares and increase the gross raw material of cotton to 84.1 thousand tons [1:32]. These strict obligations were strengthened from year to year by the local Soviet authorities. 


\section{RESULTS AND DISCUSSIONS}

In 1957, collective farmers and machine operators of Toshloq district of Ferghana region introduced the method of square-nest planting and double care of cotton in all cotton fields. In particular, the district collective farms doubled the care of cotton on 9,000 hectares of the total area of 12,000 hectares of cotton and were the first in the region to implement the state plan for cotton production [2: 87]. The average yield in the district was 27 tons in 1956 instead of 28.3 tons formed. Despite the fact that the lands attached to the Gulistan collective farm, which was established this year in Central Ferghana, are completely unsuitable for agriculture and cost a lot of manpower, materials and money, there was no average cotton harvest. In particular, the cotton harvest in 1958 was 11.70 tons, in 195911.91 tons 8.46 quintals in 1960 and 9.14 quintals in 1961, and the plan for cotton production was not fulfilled for a single year [3: 6]. That is why the financial condition of the kolkhoz as of January 1,1962, amounted to 48,000 rubles of capital debt in the card index. On January 13,1958, the Council of Ministers of the USSR adopted a resolution "On the progress of irrigation and reclamation work in Ferghana and Andizhan regions and throughout the country" [4:62]. According to the Council of Ministers of the USSR, in 1958 the state of work on the preparation of the irrigation system for vegetation (growth) irrigation, washing and reserve irrigation measures were not fully implemented. Due to this, as of January 5,1958 , the cleaning of the irrigation network in the country was completed by $58.5 \%$. At the same time, $68.2 \%$ of the plan was implemented by mechanisms and $44.3 \%$ by hand. In particular, manual cleaning of the irrigation system was completed by $2.4 \%$ in Namangan, 3.3\% in Andizhan and 7.1\% in Ferghana. The main reason for the failure of this work was the inability of the Soviet government to provide the irrigation system with sufficient machinery and equipment. Founded in 1959 in the Ferghana Valley, the "Communism" collective farm has achieved high yields of cotton and other agricultural crops.

In particular, in 1961, the collective farm increased the area from 670 hectares to 25 hectares yielded from. At the same time, the Karl Marx collective farm of the Akhunboboev Production Department, established in 1959, planted cotton on 720 hectares and in 1962 on 27.4 thousand hectares yielded from [12: 2]. In 1959-1961, the plan for the preparation of new lands in the state farm "Gulbog" Turakurgan district by the $1^{\text {st }}$ Construction and Installation Department amounted to 2675 hectares, which in practice was fulfilled by 2407 hectares or $89 \%$. During these years, the state farm "Gulbog" according to the plan was to prepare 597 hectares, but in practice it was prepared for 372 hectares or $62.3 \%$ [5: 77]. However, the production of cotton by the district collective farms during 1959-1961 decreased year by year. In 1959 the yield was 30 tons, in 196028.1 tons, in 196125.2 tons formed. As of May 10, 1963, in Central Ferghana, 9706 hectares of new lands were prepared, 7196 hectares were washed, and a total of 1991 seeds were sown. Of this, 463 hectares were planted with cotton, 1,117 hectares with maize and corn, and 411 hectares with other agricultural crops, 857 people and 75 tractors worked on the collective and state farms in these new lands [13:31]. The role of the kolkhoz mobile brigades in the development of the Central Ferghana reserve was also significant. "From 1964 to 1971, the mobile brigades of these kolkhozes acquired about 1,200 new plots of land on several plots of land. For example, the first year after its development - in 1964 - 20 tons per hectare from, in 1965 - 26.3 tons and in 197247 tons was obtained from "[15:37].

The above examples also show that cotton production in the valley area has increased significantly. Most of the cotton grown was transported to the center. It served 
to enrich the former Soviet Union's harvest, not the needs of the local population. The development of Central Ferghana lands on the basis of the policy of cotton monopoly has intensified in recent years. In particular, on November 15, 1973, a meeting of the Council of Ministers of the USSR "On the implementation of the resolution of the Central Committee of the Communist Party of Uzbekistan and the Council of Ministers of the USSR on agricultural development, irrigation, establishment of new farms and complex construction in Central Ferghana". According to the resolution of the Central Committee of the Communist Party of Uzbekistan and the Council of Ministers of the USSR of November 1, 1971 "On measures to accelerate the irrigation and agricultural development of Central Ferghana", the construction of industrial, residential and cultural facilities The implementation of the task of establishing a forest reserve of the fields planned for 19721973 was analyzed. At the same time, in 1972, with the help of the Uzgiprozem Institute of the Ministry of Agriculture of the USSR, the general scheme of organization of the Central Ferghana region was edited in cooperation with the Ministry of State Farms and the Ministry of Land Reclamation and Water Resources. Ferganavodstroy, Andizhanvodstroy and Namanganvodstroy trusts and regional irrigation departments in the Ferghana Valley carried out excavation, concrete and reinforced concrete works in the amount of 1634039 $\mathrm{m}^{3}$ for 19 years (1953-1972), of which $650526 \mathrm{~m}^{3}$ in Ferghana, $8338 \mathrm{~m}^{3}$, Andizhan, $149692 \mathrm{~m}^{3}$ fell to the Namangan region. In the first quarter of this year, the council of the Namanganvodstroy Trust set a task to add 460 hectares of new land in the first quarter of this year. In particular, as of February 8 this year, 40 new irrigated lands were developed on the second stage of the M-1 canal $4.9 \mathrm{~km}$ of pipes were laid. Construction and installation work was completed in the first ten days of February at 16 thousand rubles, or $28 \%$, instead of 57 thousand rubles. In particular, work on irrigated lands in the 184hectare Komsomol collective farm in Zadarya (Mingbulak) district, which is scheduled for commissioning in February, has not been completed. The reason for such cases is the frequent arrival of tasks of different content from the center, the urgency of their implementation, the fact that one task is not yet completed, and another is assigned.

\section{CONCLUSION}

In conclusion, it should be noted that in the 50s and 70s of the XX century in the valley agriculture dominated the policy of the Soviet cotton monopoly, where irrigation was completely subordinated to this policy. To this end, many protected lands have been developed and replaced by cotton fields. Based on this practice, the Soviet government paid close attention to getting more cotton and further expanding the area under cotton. As a result, cotton monopoly in the valley provinces intensified and the life of the peasants became increasingly difficult.

\section{REFERENCES:}

1. Andizhan Regional State Archive (ARSA), Fund - 608, List -1, folding volume - 844 .

2. ARSA, Fund - 619, List-1, folding volume - 113.

3. ARSA, Fund - 608, List - 1, folding volume - 1617.

4. ARSA, Fund - 612, List - 1, folding volume - 6 .

5. ARSA, Fund - 619, List-1, folding volume - 101.

6. Igamberdiev R.S., Razzakov A.A. The history of the land reclamation in Uzbekistan (by the materials of Mirzachul).-Tashkent: Fan, 1978. 
7. Decisions and resolution of the KPSS congresses, conferences, and the plenums of the Central Committee. Volume VI.-Tashkent: Uzbekistan, 1985.

8. Namangan Regional State Archive, Fund-275, List-1, folding volume-1341.

9. Ferghana Regional State Archive (FRSA), Fund-1151, List-1, folding volume-3.

10. FRSA, Fund-1151, List-1, folding volume - 14.

11. FRSA, Fund-1151, List-1, folding volume - 12.

12. FRSA, Fund-1151, List-1, folding volume - 78.

13. FRSA, Fund-1151, List-1, folding volume - 87.

14. Andizhan Regional Branch of the Presidency Administration archive of the Republic of Uzbekistan, Fund-155, List-1, folding volume-108.

15. Gofurov A. Economical issues of the irrigation and land reclamation.-Tashkent: Uzbekistan, 1974. 